\title{
New efficient DNA extraction method to access the microbiome of Ricinus communis seeds
}

\author{
C.D. Santos Jr., A.C.C. Dias, I.M.R. Amaral, A.M. Bonetti and \\ T.A. Campos \\ Laboratório de Genética, Instituto de Genética e Bioquímica, \\ Universidade Federal de Uberlândia, Uberlândia, MG, Brasil \\ Corresponding author: C.D. Santos Jr. \\ E-mail: celio.diasjunior@gmail.com
}

Genet. Mol. Res. 12 (3): 3128-3135 (2013)

Received July 4, 2012

Accepted November 22, 2012

Published February 28, 2013

DOI http://dx.doi.org/10.4238/2013.February.28.23

\begin{abstract}
Ricinus communis (castor bean) seeds are used to produce an alcohol-soluble oil that is used in more than 400 industrial processes. Despite its economic importance, there has been little research on the endophytic microbiota of castor bean seeds. This microbiota is important for plant metabolic processes and may have considerable biotechnological potential, such as production of lipases and plant growth promoter agents. We evaluated several DNA extraction methodologies in order to access the microbial diversity of castor bean through a metagenomic approach. Based on our observations, we developed a new methodology that takes advantage of the low solubility of calcium phosphates and the high affinity of these phosphates for proteins and polysaccharides. The extracted DNA quality was evaluated by PCR, using a selective primer pair for bacterial and mitochondrial 16S rDNA genes $(799 \mathrm{~F}$ and $1492 \mathrm{R})$. We found this methodology quantitatively and qualitatively more efficient than the other approaches. In evaluating this new extraction methodology, we found that the difficulties of DNA extraction from castor bean seeds, such as abundant oil, polysaccharides, phenolic compounds, and plant enzymes, could be overcome. The resulting extracts had high concentration and purity,
\end{abstract}


and they were obtained faster than with previous methods. The samples contained virtually all of the DNA, including the microbial DNA; this was validated by PCR analysis.

Key words: DNA extraction; Castor bean; Endophytic microbiota; Metagenomic; Selective PCR

\section{INTRODUCTION}

Castor bean oil is obtained through simple extraction processes and has unusual properties, such as alcohol solubility. This feature allows the use of castor bean in more than 400 industrial manufacturing processes including soaps, lubricants, hydraulic and brake fluids, paints, and dyes. In addition to oil production, other possibilities of this plant include the use of its leaves as silkworm food, mixing with forage to increase milk secretion in dairy cattle, and use of the stem in the manufacture of paper (Azevedo and Beltrão, 2008).

The establishment of plants in habitats requires interaction with various environments and living organisms. We highlight those that occur between plant and microbial endophytes, which can be mutualistic, symbiotic, or even proto-cooperational. In this context, the use of microorganisms in agricultural practices has increased substantially to improve plant growth and provide biological control of plant diseases. They are used as chemical compound substitutes, thus favoring environmental preservation (Peixoto Neto et al., 2002).

Despite the economic importance of castor bean oil, studies of its endophytic microbiota are rare, and most simply address the isolation and characterization of microorganisms by methods that do not encompass the total biodiversity of the sample. Knowledge of endophyte biodiversity is important because these microorganisms are often advantageous for the plant and can be used to develop cheaper, less invasive agricultural processes. However, isolation and characterization by conventional microbiological methods do not enable a complete representation of the biodiversity of the endophytic community (Azevedo et al., 2000; Peixoto Neto et al., 2004; Ryan et al., 2008). Thus, culture-independent methods are needed to characterize the endophytic microbial biodiversity in castor bean.

Metagenomics was conceived as the direct isolation of DNA from a specific environment, followed by cloning of the entire genome of the microbial population within the sample (Langer et al., 2006). The resulting genomic library is used to identify sequences of interest, sequencing of microbial genomes, and phylogenetic inference. For biodiversity studies and phylogenetic inference, genes known as "phylogenetic anchors" are sequenced. Genes are highly conserved between microbial species and their low divergence may reflect speciation. Genes encoding subunit $16 \mathrm{~S}$ ribosomal RNA (16S rDNA) are used for this purpose due their highly conserved 5'- and 3'-sequences. 16S rDNA sequence comparison is used for conventional and metagenomic phylogenetic studies (Schloss and Handelsman, 2003). These genes may be amplified from a DNA sample, cloned, and sequenced, or accessed in a genomic library by PCR or hybridization for subsequent sequencing (Rajendhran and Gunasekaran, 2008; Yu et al., 2008).

Metagenomics has become popular in ecological studies and bioprospecting as it allows access to the genomes of microbial populations that have not yet been characterized due to difficulties in culturing and isolation (Langer et al., 2006; Sleator et al., 2008). The success of metagenomic studies depends on the essential first step of optimization of the DNA extrac- 
tion protocol for the environment of interest. The extraction method allows us to obtain DNA with the necessary quality and quantity for molecular cloning. In castor bean seeds, DNA extraction is critical due to the presence of many interfering substances such as phenols, tannins, carbohydrates, and lipids, which are difficult to remove. We evaluated and developed a novel protocol for total DNA extraction from castor bean seeds.

We present a relatively quick and inexpensive protocol for total DNA extraction from castor beans that provides clean DNA that can be PCR-amplified with a selective primer pair for bacterial and mitochondrial 16S rDNA (799F and 1492R).

\section{MATERIAL AND METHODS}

Castor bean seeds were collected from spontaneously grown Ricinus communis L. on the "Recanto Florido" farm $\left(1^{\circ} 33^{\prime} 12.96 " \mathrm{~S}-47^{\circ} 10^{\prime} 13.10^{\prime \prime}\right)$ near Araxá, MG, Brazil, in October and November 2010. The material was disinfected as suggested by Assumpção et al. (2009). The disinfection process was validated by plating rinse water on Luria Bertani agar (10 $\mathrm{g} / \mathrm{L} \mathrm{NaCl} ; 10 \mathrm{~g} / \mathrm{L}$ tryptone; $5 \mathrm{~g} / \mathrm{L}$ yeast extract; $1.5 \%$ agar). The absence of bacterial and fungal growth after $72 \mathrm{~h}$ at $28.5^{\circ} \mathrm{C}$ validated the disinfection.

After disinfection, seed coats were excised using a sterile scalpel blade. Endosperms with the embryo were placed in an autoclaved pestle and ground in liquid nitrogen to a fine powder. Aliquots of this material were manipulated with a sterile spatula. Each aliquot was subjected to a different extraction methodology, and each method was performed in quadruplicate. Six different extraction protocols were tested (Table 1).

\begin{tabular}{|c|c|c|}
\hline Name & Modifications & Reference \\
\hline$\overline{\mathrm{MB}}$ & - & Mogg and Bond (2003) \\
\hline $\mathrm{OL}$ & $\begin{array}{l}\text { Organic extractions with phenol:chloroform:isoamyl alcohol }(25: 24: 1) \text { and two with } \\
\text { chloroform:isoamyl alcohol }(24: 1)\end{array}$ & Oliveira et al. (2007) \\
\hline $\mathrm{ON}$ & $\begin{array}{l}\text { Incubation of the mash at } 100^{\circ} \mathrm{C} / 5 \mathrm{~min} \text { before the start of the process in order to } \\
\text { inactivate nucleases }\end{array}$ & Oliveira et al. (2007) \\
\hline $\mathrm{OM}$ & $\begin{array}{l}3 \text { extractions with chloroform:isoamyl alcohol (24:1) and not used the } \\
\text { proteinase } \mathrm{K}(10 \mathrm{mg} / \mathrm{mL})\end{array}$ & Oliveira et al. (2007) \\
\hline PA & - & Rogers and Bendich (1988) \\
\hline ExE & - & Xavier et al. (2004) \\
\hline
\end{tabular}

Name refers to the symbols used in the report.

After testing these methodologies, we propose a DNA extraction method (ExO) as follows: the crushed sample in liquid nitrogen is maintained at room temperature. Aliquots of 150 $\mu \mathrm{L} / \mathrm{g}$ sterile $\mathrm{PBS}\left(140 \mathrm{mM} \mathrm{NaCl}, 3 \mathrm{mM} \mathrm{KCl}, 10 \mathrm{mM} \mathrm{Na}_{2} \mathrm{HPO}_{4}\right.$, and $\left.2 \mathrm{mM} \mathrm{KH}_{2} \mathrm{PO}_{4}, \mathrm{pH} 7.2\right)$ and $155 \mu \mathrm{L} / \mathrm{g}$ TE buffer (10 mM Tris-HCl, $1 \mathrm{mM}$ EDTA, $\mathrm{pH}$ 8.0, autoclaved) were added to samples that were homogenized with a spatula. This mixture was distributed in aliquots of 300-100 $\mathrm{mg}$ in 2-mL tubes for DNA extraction. In each tube, $0.9 \mathrm{~mL} 1 \%(\mathrm{w} / \mathrm{v})$ sterile $\mathrm{CaCl}_{2}$ was added. The tubes were vortexed for $30 \mathrm{~s}$ and incubated at room temperature for $8 \mathrm{~min}$. The supernatant was carefully transferred to a new tube and centrifuged at $4500 \mathrm{~g}$ for $5 \mathrm{~min}$ (it is optional, to facilitate the homogenization). Then, $100 \mu \mathrm{L} 30 \%$ SDS and $200 \mu \mathrm{L}$ TE buffer were added to the suspension, vortexed for $45 \mathrm{~s}$, and centrifuged at $4500 \mathrm{~g}$ for $5 \mathrm{~min}$ at $4^{\circ} \mathrm{C}$. The interface suspension was transferred to a new tube with $500 \mu \mathrm{L}$ phenol:chloroform:isoamyl alcohol (25:24:1; PCI). The 
tubes were vortexed again for $10 \mathrm{~s}$ and centrifuged at $14,000 \mathrm{~g}$ for $10 \mathrm{~min}$ at $4^{\circ} \mathrm{C}$. The upper phase was collected and again extracted with PCI. The aqueous phase was transferred to a fresh tube. A cold solution of $1 / 10$ volume $3 \mathrm{M}$ sodium acetate, $\mathrm{pH} 4.6$, and 7/10 volume isopropanol was added, and the suspension was mixed by inversion. The precipitated DNA was incubated at $-20^{\circ} \mathrm{C}$ for $1 \mathrm{~h}$, and pelleted by centrifugation at $14,000 \mathrm{~g}$ for $30 \mathrm{~min}$ at $4^{\circ} \mathrm{C}$. The pellet was washed with $0.5 \mathrm{~mL} 70 \%$ cold ethanol and centrifuged at $14,000 \mathrm{~g}$ for $10 \mathrm{~min}$ at $10^{\circ} \mathrm{C}$. The pellet was left in a laminar flow hood for $5 \mathrm{~min}$, resuspended in $100 \mu \mathrm{L}$ TE buffer with $5 \mu \mathrm{L} 10 \mathrm{mg} / \mathrm{mL}$ RNase, and stored at $-20^{\circ} \mathrm{C}$.

An aliquot of each DNA extract $(5 \mu \mathrm{L})$ was separated by agarose gel electrophoresis [1\% (w/v) agarose; $0.2 \mu \mathrm{g} / \mathrm{mL}$ ethidium bromide] at $120 \mathrm{~V}$ for $40 \mathrm{~min}$. All extraction productions were quantified on a Nanodrop ND-1000 (Thermo Scientific).

To analyze the calcium phosphate crystals formed during DNA extraction, we used the pellet from the first high-speed centrifugation $(4500 \mathrm{~g}$ ), resuspended in $500 \mu \mathrm{L} \mathrm{95 \%} \mathrm{ethanol,} \mathrm{and}$ vortexed for $30 \mathrm{~s}$. To study the adsorbed protein, $50 \mu \mathrm{L}$ resuspended material was placed on a slide with $50 \mu \mathrm{L}$ Bradford reagent (Bradford, 1976), kept in the dark for $15 \mathrm{~min}$, then analyzed by light microscopy (Olympus $\mathrm{CH} 2$ ). To analyze the adsorbed nucleic acids, another slide was made with $50 \mu \mathrm{L}$ material dried in a stove and fixed in a mixture of $50 \mu \mathrm{L} 5 \mathrm{M} \mathrm{HCl}$ and $50 \mu \mathrm{L} 1 \mathrm{M}$ methanol. After $15 \mathrm{~min}$ at room temperature, the slide was dried and $50 \mu \mathrm{L}$ Schiff's reagent $(1 \mathrm{~g} / \mathrm{L}$ fuchsin, $25 \mathrm{~g} / \mathrm{L}$ sodium bisulfite, $15 \mathrm{~mL} / \mathrm{L} 1 \mathrm{M} \mathrm{HCl}$ ) was added. The slide was incubated with a coverslip in the dark for $30 \mathrm{~min}$ (Hillary, 1939; Lessler, 1951) and analyzed by light microscopy. To verify the presence of adsorbed starch or other polysaccharides, we added $50 \mu \mathrm{L}$ resuspended pellet to a slide with $50 \mu \mathrm{L}$ iodine tincture [5\% (w/v) iodine in $100 \%$ ethanol]. After $5 \mathrm{~min}$, a coverslip was placed above the drop and the slide was analyzed by light microscopy.

The extracted mixtures of bacterial and plant DNA were analyzed with a specific bacterial $16 \mathrm{~S}$ rDNA primer to compare the DNA quality in each mixture. Amplification was performed with primers: 799F (5'-ATTAGATACAACMGGCCKG-3') (Chelius and Triplett, 2001) and universal primer 1492R (5'-TACGGHTACCTTGTTACGACTT-3') (Lane, 1991). The reaction was performed in a final volume of $25 \mu \mathrm{L}$ containing $100 \mathrm{ng}$ DNA, 1X Taq buffer, $0.1 \mathrm{mM}$ of each dNTP, $2.5 \mathrm{mM} \mathrm{MgCl}, 5$ pmol of each primer, $1 \mathrm{U}$ Taq DNA polymerase, and sterilized ultrapure water. PCR was performed in a GeneAmp 9700 (Applied Biosystems) thermal cycler with the following protocol: preheating $\left(95^{\circ} \mathrm{C}, 3 \mathrm{~min}\right), 35$ cycles at $94^{\circ} \mathrm{C}$ for 20 $\mathrm{s}, 53^{\circ} \mathrm{C}$ for $40 \mathrm{~s}$, and $72^{\circ} \mathrm{C}$ for $1 \mathrm{~min}$, and a final extension at $72^{\circ} \mathrm{C}$ for $10 \mathrm{~min}$.

The PCR product separated on $1.5 \%(\mathrm{w} / \mathrm{v})$ agarose gel with $0.2 \mu \mathrm{g} / \mathrm{mL}$ ethidium bromide and electrophoresis at $120 \mathrm{~V}$ for $40 \mathrm{~min}$ in $0.5 \mathrm{X}$ TBE (45 mM Tris-borate, $\mathrm{pH} \mathrm{8.0).} \mathrm{A}$ mitochondrial DNA product of $\sim 1.5 \mathrm{~kb}$ and a bacterial product of $\sim 0.756 \mathrm{~kb}$ (Chelius and Triplett, 2001) in the same extract were considered to represent a valid extraction.

Statistical analysis included ANOVA and the Tukey test at a 5\% probability threshold.

\section{RESULTS AND DISCUSSION}

The main difficulty of DNA extraction from castor bean seeds is the presence of carbohydrates and proteins that reduce the quality of the extract (Gomes et al., 2011). Highquality DNA is extremely important to the fidelity of the procedures that follow. The presence of protein, starch, or other polysaccharides reduces Taq DNA polymerase efficiency, compromising the products to be cloned and sequenced, making it necessary to concentrate the DNA 
and remove contaminants (Nunes et al., 2011).

The proposed methodology presented satisfactory DNA yields from $R$. communis. In all methodologies, a significant amount of carbohydrates remained in the final extract; we propose additional phenol extractions to remove them.

Table 2 shows the average DNA concentrations produced by each extraction methodology, and Figure 1 shows the relative quality of each extract. Every extraction yielded a good electrophoresis profile, but the OM extraction (see Table 1) showed DNA degradation. All samples were RNA free.

Table 2. Summary statistics for the analysis of DNA extraction methods.

\begin{tabular}{lcc}
\hline Method & Binary presence/absence of PCR bands (means \pm SD) & Concentration (means \pm SD) \\
\hline MB & $0.714 \pm 0.95^{\mathrm{b}}$ & $55.67 \pm 13.54^{\mathrm{b}}$ \\
ON & $1.67 \pm 0.58^{\mathrm{b}}$ & $63.46 \pm 39.45^{\mathrm{b}}$ \\
OM & $0.0 \pm 0.0^{\mathrm{b}}$ & $359.67 \pm 316.16^{\mathrm{b}}$ \\
OL & $1.33 \pm 0.58^{\mathrm{b}}$ & $98.82 \pm 122.74^{\mathrm{b}}$ \\
PA & $1.33 \pm 0.58^{\mathrm{b}}$ & $4488.37 \pm 1219.19^{\mathrm{a}}$ \\
ExE & $0.33 \pm 0.58^{\mathrm{b}}$ & $0.00 \pm 0.00^{\mathrm{c}}$ \\
EXO & $2.00 \pm 0.00^{\mathrm{a}}$ & $583.69 \pm 878.20^{\mathrm{b}}$ \\
\hline
\end{tabular}

For method abbreviations, see Table 1. For ExO, see Material and Methods. Average of DNA concentrations (ng/ $\mu \mathrm{L})$ of the extracts from different methods and binary distribution of presence and absence of bands in PCR. a,b,c Average from the Tukey test at $5 \%$.

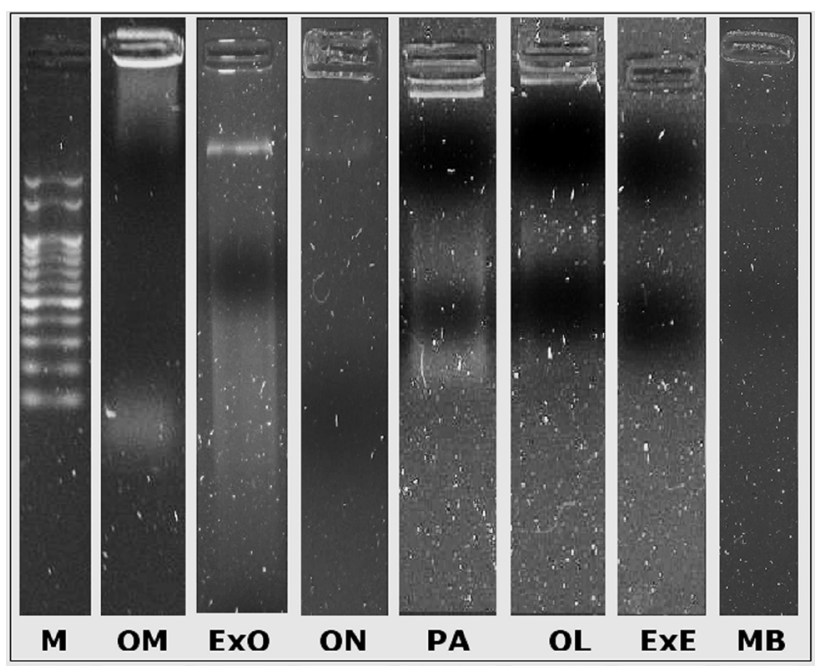

Figure 1. Products of total DNA extraction obtained using the different methodologies. Lane $M=$ marker (100-bp Sharp ladder). Agarose $1 \%$ gel, electrophoresis at $100 \mathrm{~V}$ for $40 \mathrm{~min}$ in $0.5 \mathrm{X}$ TBE. For abbreviations, see Table 1 . For ExO, see Material and Methods.

The analysis of variance showed a difference between at least one of the means $(\mathrm{P}<$ 0.05). The Tukey test suggested that the best methods were the ones suggested by Rogers and Bendich (1988) and the ExO proposed in this report. PCR amplification of 16S rDNA (Figure 2) revealed that ExO, MB2, MB5, and OL1 produced both expected amplicons (1.5 kb and $756 \mathrm{bp}$ ). However, only the ExO DNA extraction methodology provided acceptable results for 
both amplicons in all samples. The data were into numeric matrices for the presence/absence of bands (classifying each sample in $0=$ absence, $1=$ presence of just 1 band, or $2=$ presence of both bands) and the significant differences were determined by the Fisher F-test $(\mathrm{P}<0.05)$. The Tukey test at $5 \%$ revealed the superiority of the proposed method (Table 2 ).

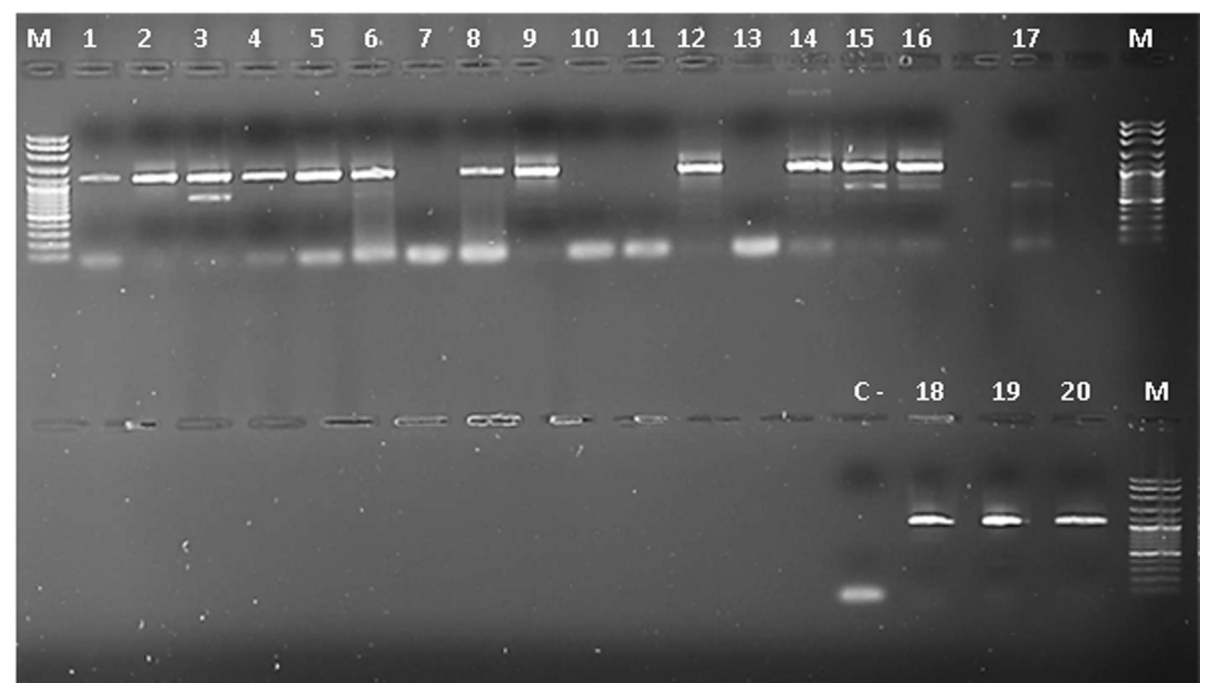

Figure 2. Triplicates of the PCR amplicons, showing both bands, mitochondrial and bacterial, from different methods of DNA extraction. Lanes 1,2, and $3=\mathrm{OL}$; lanes 4, 5, and $6=\mathrm{ON}$; lanes 7, 8, 9, and $12=\mathrm{MB}$; lane 10, 11,13 , and $17=\mathrm{ExE}$; lanes 14,15 , and $16=\mathrm{ExO}$; lanes 18,19 , and $20=\mathrm{PA}$; lane $C$ - $=$ control without DNA; and lane $M=100$-bp Sharp ladder. Agarose $1 \%$ gel with $0.2 \mu \mathrm{g} / \mathrm{mL}$ ethidium bromide, electrophoresis at $100 \mathrm{~V}$ for 50 min. For abbreviations, see Table 1. For ExO, see Material and Methods.

DNA electrophoresis and PCR (Figures 1 and 2) suggested that PA (see Table 1) was one of the best DNA extraction methodologies; however, reproducibility was low. Thus, the method should not be used for metagenomic studies due to the risk of losing some genetic material.

The OL methodology (see Table 1) resulted in a cleaner extract; however, reproducibility and PCR-amplification were poor (Figure 1). This methodology was originally used for genomic studies (Oliveira et al., 2007), producing high-integrity DNA of high molecular weight, but we do not consider it appropriate for metagenomic studies due to inconsistent amplification quality. The OM method (see Table 1) yielded the worst results, probably due to the high-temperature nuclease inactivation. Reproducibility was poor and the products could not be used for genomic and metagenomic purposes. The MB methodology (see Table 1) provided good results, yielded poor amplification, and low sample concentrations; the method is also difficult and time-consuming.

ExO was the best extraction method, yielding high DNA concentrations and consistent, quality sample amplifications. In addition, the ExO methodology was tested without PCI extractions (data not shown); these modifications did not significantly differ in efficiency and yield; products were amplified easily and protein/RNA contamination was not detectable, and thus the method was time-saving.

The apparent success of the ExO methodology comes from the reaction between cal- 
cium chloride and PBS salts at neutral $\mathrm{pH}$, generating calcium phosphate precipitates (Rigo et al., 2007; Guastaldi and Aparecida, 2010). The precipitated nanocrystals adsorbed proteins (Figure 3) via interaction between the protein group $\left(\mathrm{NH}_{4}^{+}\right)$and the crystal group $\left(\mathrm{PO}_{4}^{-}\right)$or complex formation between $\mathrm{HA}-\mathrm{Ca}_{2}{ }^{+}-{ }^{-} \mathrm{OOC}$-protein keeping only the nucleic acids of the ground material in contact with organic phases of the extraction process. The hydroxyapatite and octacalcic phosphate precipitates formed the cell debris, based on the principle underlying the use of silica beads for DNA (Rojas-Herrera et al., 2008); this idea is already used in HPLC (Guastaldi and Aparecida, 2010). Formation of these insoluble phosphates is similar to the biomimicking process proposed by Abe et al. (1990).

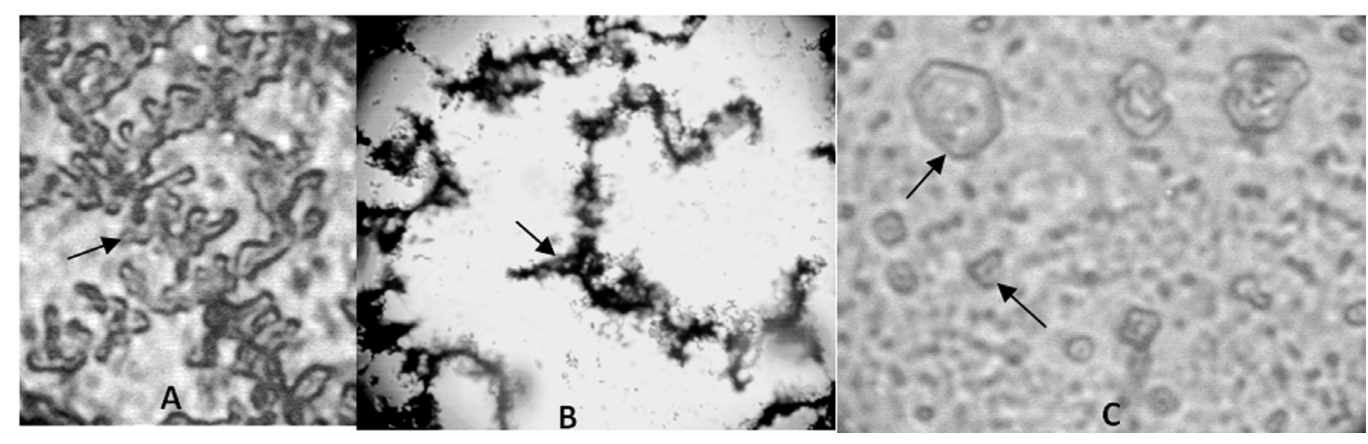

Figure 3. Crystals of calcium phosphates. A. DNA stained with the Schiff reactive The compound stained all medium, not only the crystal surface (arrow), indicating that the DNA is not exclusively adsorbed. B. Polysaccharide adsorbed at the crystal surface forming a super-polymer that looks as a macroarrayed structure (arrow) stained by iodine. C. Protein adsorbed at the crystal surface and differential nucleation (arrows) stained with the Bradford reactive (100X magnification).

The proposed methodology can be used for all genomic and metagenomic purposes, not only metagenomics, and can be easily modified for material specificity. It is time-efficient and can be used to study processes that occur during calcification. The most interesting finding in this study was the use of calcium deposition for a more robust DNA extraction that can be used for diverse proposals.

\section{CONCLUSIONS}

The method (ExO) proposed here proved to be the most efficient and reliable for total DNA extraction from $R$. communis (castor bean) for metagenomic approaches in comparison to others proposed in the literature. This methodology may easily be modified according to the plant material.

\section{ACKNOWLEDGMENTS}

Research supported by Fundação de Apoio Universitário, Universidade Federal de Uberlândia (FAU/UFU), Fundação de Apoio à Pesquisa de Minas Gerais (FAPEMIG), and CNPq. A.C.C. Dias received a student scholarship from FAPEMIG BIO-009 project. We are also grateful to Laboratório de Genética (LABGEN) of Instituto the Genética e Bioquímica (INGEB/UFU) team. 


\section{REFERENCES}

Abe Y, Kokubo T and Yamamuro T (1990). Apatite coating on ceramics, metals and polymers utilizing a biological process. J. Mater. Sci. Mater. Med. 1: 233-238.

Assumpção LC, Lacava PT, Dias ACF, Azevedo JL, et al. (2009). Diversidade e potencial biotecnológico da comunidade bacteriana endofítica de sementes de soja. Pesq. Agropec. Bras. 44: 503-510.

Azevedo DMP and Beltrão NEM (2008). O Agronegócio da Mamona no Brasil. 3rd edn. Embrapa, Campina Grande.

Azevedo JL, Maccheroni W Jr, Pereira JO and Araújo WL (2000). Endophytic microorganisms: a review on insect control and recent advances on tropical plants. EJB 3: 40-65.

Bradford MM (1976). A rapid and sensitive method for the quantitation of microgram quantities of protein utilizing the principle of protein-dye binding. Anal. Biochem. 72: 248-254.

Chelius MK and Triplett EW (2001). The diversity of archaea and bacteria in association with the roots of Zea mays L. Microb. Ecol. 41: 252-263.

Gomes FHT, Cândido MJD, Pereira ES, Lopes JWB, et al. (2011). Composição bromatológica e degradação in situ de subprodutos da cadeia do biodiesel. Rev. Cient. Prod. Anim. 11: 144-156.

Guastaldi AC and Aparecida AH (2010). Fosfatos de cálcio de interesse biológico: importância como biomateriais, propriedades e métodos de obtenção de recobrimentos. Quim. Nova 33: 1352-1358.

Hillary B (1939). Use of the Feulgen reaction in cytology I. Effect of fixatives on the reaction. Bot. Gaz. 101: 276-300.

Lane DJ (1991). 16S/23S rRNA Sequencing. In: Nucleic Acid Techniques in Bacterial Systematics (Stackebrandt E and Goodfellow M, eds.). John Wiley \& Sons, New York, 115-175.

Langer M, Gabor EM, Liebeton K, Meurer G, et al. (2006). Metagenomics: an inexhaustible access to nature's diversity. Biotechnol. J. 1: 815-821.

Lessler MA (1951). The nature and specificity of the Feulgen reaction. Arch. Biochem. Biophys. 32: 42-54.

Mogg RJ and Bond JM (2003). A cheap, reliable and rapid method of extracting high-quality DNA from plants. Mol. Ecol. Notes 3: 666-668.

Nunes CF, Ferreira JL, Fernandes MCN, Breves SS, et al. (2011). An improved method for genomic DNA extraction from strawberry leaves. Cienc. Rural 41: 1383-1389.

Oliveira MCS, Regitano LCA, Roese AD, Anthonisen DG, et al (2007). Fundamentos Teórico-Práticos e Protocolos de Extração e de Amplificação de DNA por Meio da Técnica da Reação em Cadeia da Polimerase. Embrapa, Brasília.

Peixoto Neto PAS, Azevedo JL and Araújo WL (2002). Microrganismos endofíticos. Biotecnol. Cienc. Desenvol. 29: $62-77$.

Peixoto Neto PAS, Azevedo JL and Caetano LC (2004). Microrganimos endofíticos em plantas: status atual e perspectivas. BLACPMA 3: 69-72.

Rajendhran J and Gunasekaran P (2008). Strategies for accessing soil metagenome for desired applications. Biotechnol. $A d v .26: 576-590$.

Rigo E, Gehrke S and Carbonari M (2007). Síntese e caracterização de hidroxiapatita obtida pelo método da precipitação. Rev. Dental Press Periodontia Implantol. 1: 39-50.

Rogers SO and Bendich AJ (1988). Extraction of DNA from plant tissues. Plant Mol. Biol. 5: 69-76.

Rojas-Herrera R, Narvaez-Zapata J, Zamudio-Maya M and Mena-Martinez ME (2008). A simple silica-based method for metagenomic DNA extraction from soil and sediments. Mol. Biotechnol. 40: 13-17.

Ryan RP, Germaine K, Franks A, Ryan DJ, et al. (2008). Bacterial endophytes: recent developments and applications. FEMS Microbiol. Lett. 278: 1-9.

Schloss PD and Handelsman J (2003). Biotechnological prospects from metagenomics. Curr. Opin. Biotechnol. 14: 303310.

Sleator RD, Shortall C and Hill C (2008). Metagenomics. Lett. Appl. Microbiol. 47: 361-366.

Xavier GR, Silva FV, Zilli JE and Rumjanek NG (2004). Adaptação de Método para Extração de DNA de Microrganismos Associados a Raízes de Plantas - Documento 171. Embrapa Agrobiologia, Seropédica.

Yu WH, Su SC and Lee CY (2008). A novel retrieval system for nearly complete microbial genomic fragments from soil samples. J. Microbiol. Methods 72: 197-205. 